\title{
Можливості хірургічного лікування аспергільозу легень
}

\author{
М. С. Опанасенко, О. Е. Кшановський, Б. М. Конік, О. В. Терешкович, \\ М. І. Калениченко, Л. І. Леванда \\ Національний інститут фтизіатрії і пульмонології імені Ф. Г. Яновського НАМН України, м. Київ
}

\section{Possibilities of surgical treatment of pulmonary aspergillosis}

\author{
M. S. Opanasenko, O. E. Kshanovskyi, B. M. Konik, O. V. Tereshkovych, \\ M. I. Kalenychenko, L. I. Levanda \\ Yanovskyi National Institute of Phthisiatry and Pulmonology, Kyiv
}

\section{Реферат}

Мета. Поділитися власним досвідом хірургічного лікування аспергільозу легень.

Матеріали і методи. За останні 10 років у клініці перебували 14 хворих з аспергільозом легень. У 11 (78,6\%) хворих діагностовано аспергілому легені, у $3(21,4 \%)$ - інвазивний аспергільоз після проведення біопсії легені. Резекційні втручання виконані 8 (57,1\%) пацієнтам з аспергіломою. Відмовлено в операції внаслідок значних дихальних розладів 3 $(21,4 \%)$ хворим. Середній вік пацієнтів - $(42,6 \pm 15,7)$ року. Всі пацієнти до і після оперативного втручання отримували специфічну протигрибкову терапію.

Результати. Виконано такі оперативні втручання: 3 (37,5\%) плевропульмонектомії, 4 (50,0\%) лобектомії, 1 (12,5\%) типову резекцію піраміди та S3 справа. У 1 (12,5\%) пацієнтки під час оперативного втручання виконано інтраплевральну торакопластику. Середня тривалість операції склала $(235,6 \pm 77,6)$ хв, середня інтраопераційна крововтрата - $(314 \pm$ 331,9) мл.

Висновки. Хірургічне лікування аспергільозу легень є досить складним завданням і має багато невирішених питань. Систематизація власного досвіду та досвіду, про який повідомляють інші дослідники, дає змогу покращити результати лікування.

Ключові слова: легеневий аспергільоз; аспергілома; резекція; торакопластика.

Abstract

Objective. To share own experience of surgical treatment of pulmonary aspergillosis.

Materials and methods. Through last 10 years in the clinic 14 patients, suffering pulmonary aspergillosis, were treated. In 11 (78.6\%) patients pulmonary aspergillosis was diagnosed, and in $3(21.4 \%)$ - invasive aspergillosis after performance of pulmonary biopsy. Resection interventions were done in 8 (57.1\%) patients, suffering aspergilloma. In 3 (21.4\%) patients, in whom significant respiratory disorders existed, the operation was contraindicated. Average age of the patients have constituted (42.6 \pm 15.7 ) years old. All the patients received specific antifungal therapy before and after the operation

Results. There were performed following operative interventions: $3(37.5 \%)$ pleuropulmonectomies, 4 (50.0\%) lobectomies, $1(12.5 \%)$ typical resection of pyramid and right-sided S3a. In 1 (12.5\%) woman patient intrapleural thoracoplasty was performed. Average duration of the operation was (235.6 \pm 77.6$)$ min, average intraoperative blood loss - $(314 \pm 331.9) \mathrm{ml}$. Conclusion. Surgical treatment of pulmonary aspergillosis constitutes a complex task and has many unsolved issues. Systematization of own experience and experience of other investigations reported, permits to improve the treatment results.

Keywords: pulmonary aspergillosis; aspergilloma; resection; thoracoplasty.

Легеневий аспергільоз виникає внаслідок колонізації грибами роду Aspergillus fumigatus тканини легень. Збудники інфекції зустрічаються повсюдно. Їх спори через повітря потрапляють на слизову оболонку дихальних шляхів, навколоносових пазух і завдяки малим розмірам (2,5 - 3,0 мкм) можуть досягати альвеол. Хоч аспергіли є повсюдно, імунокомпетентні особи не хворіють на аспергільоз. Для розвитку патологічного процесу необхідний комплекс умов і причин: висока інфікуюча доза, безсимптомне носійство, зниження імунітету внаслідок антибактеріальної або імуносупресивної терапіі, тривале існування порожнин розпаду в легенях тощо [1-3].

Розрізняють чотири клінічні форми аспергільозу легень - хронічний некротизуючий, алергічний бронхолегеневий, інвазивний та аспергілома. Перші три форми аспергільозу є терапевтичною проблемою і з хірургічної точки зору інтересу не становлять. Коли діагностичний пошук утруднений, необхідне проведення біопсії легені з наступними мікробіологічним і гістологічним дослідженнями для встановлення точного діагнозу [4].

Основні методи діагностики аспергільозу легень: комп’ютерна томографія (КТ) органів грудної порожнини високої роздільної здатності; серологічні - виявлення антигену галактоманану в бронхоальвеолярному змиві, в сироватці крові або біопсійному матеріалі; мікроскопія і посів мокротиння або біопсійного матеріалу $[1,5]$. У нашій країні туберкульоз має значну поширеність. Тому Aspergillus fumigatus досить часто колонізує туберкульозні порожнини розпаду у хворих, що призводить до формування аспергіломи. Також аспергілома може утворюватись в бронхоектазах нетуберкульозної етіології, хронічних абсцесах, кістах, булах, в пухлинному вузлі з розпадом $[2,6,7]$. На томограмах аспергілома 


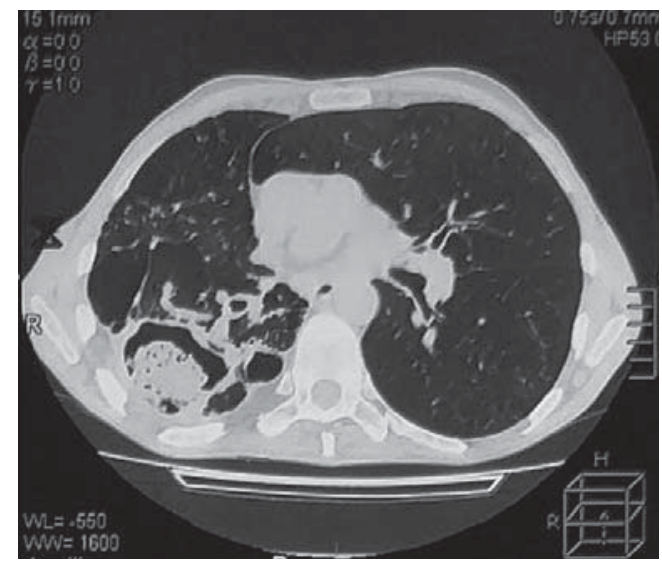

A

має вигляд кулі всередині порожнини. Оскільки їі основна маса зазвичай відділена від контурів порожнини повітряним простором, даний симптом дістав назву «повітряного півмісяця» (ознака Монода) (див. рисунок) [1, 4, 8].

Основним проявом захворювання є рецидивуюче кровохаркання (у 70 - 80\% хворих). У 20 - 25\% хворих кровохаркання загрожує їх життю, оскільки може перейти в легеневу кровотечу. Гриб у процесі росту виділяє токсин, який ерозує стінки порожнини та прилеглі структури, в тому числі судини [1].

Аспергіломи поділяють на прості й складні. Складна аспергілома має виражену клінічну симптоматику, рентгенологічно фіксують значні перикавітарні інфільтрати, розвиваються нові або збільшуються старі порожнини деструкції. Для простої аспергіломи характерний безсимптомний перебіг [1].

Враховуючи невизначеність у методах і термінах лікування пацієнтів з аспергіломою, ми ділимося власним досвідом хірургічного лікування даного захворювання в нашій клініці, який базується на рекомендаціях зарубіжних дослідників та власних дослідженнях.

\section{Матеріали і методи дослідження}

У період з 2007 по перше півріччя 2017 року у відділенні торакальної хірургії і інвазивних методів діагностики Інституту перебували 14 хворих з аспергільозом легень. У 11 (78,6\%) хворих діагностовано аспергілому легені, у 3 (21,4\%) - інвазивний аспергільоз після проведення біопсії легені. Різні резекційні втручання виконані 8 (57,1\%) пацієнтам з аспергіломою. Відмовлено в операції внаслідок значних дихальних розладів 3 (21,4\%) хворим.

Серед прооперованих пацієнтів чоловіків і жінок було порівну (4 чоловіки і 4 жінки). Середній вік пацієнтів - 42,6 року (від 32 до 63 років). У 5 (62,5\%) хворих симптомом аспергіломи було рецидивуюче кровохаркання, що стало основним приводом до хірургічного методу лікування. Фоном для виникнення аспергіломи у 5 (62,5\%) хворих (3 чоловіків і 2 жінок) був туберкульоз легень або посттуберкульозні зміни, в 1 (12,5\%) пацієнтки - бульозна хвороба (в поєднанні з первинним імунодефіцитом). Ще в 1 хворого аспергілома розвинулась всередині злоякісної пухлини з розпадом. Фонові захворювання до операції тривали від 2 до 108 міс. Супутню патологію мали 6 (75,0\%) пацієнтів.
B

\section{Результати}

Всі пацієнти з діагнозом аспергіломи до і після оперативного втручання отримували специфічну протигрибкову терапію. Тривалість такого лікування на доопераційному етапі залежала від рентгенологічних даних і клінічних проявів захворювання, а основним завданням було стабілізувати інфекційний процес. Середня тривалість лікування в післяопераційному періоді склала 3 міс.

Плевропульмонектомію виконали 3 (37,5\%) хворим з аспергіломою, у тому числі 1 (12,5\%) пацієнтці - 3 відеоасистенцією. У 3 (37,5\%) хворих виконали верхню лобектомію справа, у тому числі в 1 (12,5\%) пацієнтки операція була доповнена коригуючою чотирьохреберною екстра-інтраплевральною торакопластикою, в 1 (12,5\%) - зліва. Ще 1 хворій виконана типова резекція піраміди та S3 справа.

Середня тривалість оперативного втручання - (235,6 \pm 77,6) хв (від 120 до 320 хв), середня інтраопераційна крововтрата - (314 \pm 331,9) мл (від 50 до 1100 мл). Середня тривалість лікування в післяопераційному періоді - 33 дні (від 14 до 86 днів).

Інтраопераційні ускладнення виникли у 2 хворих. Зокрема, пошкодження лівої підключичної артерії у пацієнта $з$ хворобою Бехтерєва, якому виконали лівобічну плевропульмонектомію з приводу аспергіломи верхньої частки лівої легені, ускладненої рецидивуючим кровохарканням, і хронічної емпієми плеври зліва. Емпієма призвела до вираженого злукового процесу та значного потовщення плевральних листків, що значно ускладнило пневмоліз. Дефект пошкодженої артерії ліквідували за допомогою судинного шва. У даного пацієнта післяопераційний період ускладнився розвитком емпієми лівої плевральної порожнини з бронхіальною норицею. У зв'язку з цим було проведено бронхоблокацію кукси лівого головного бронха.

У 1 пацієнта під час виконання верхньої лобектомії зліва зупинилась серцева діяльність. Шляхом прямого масажу серця серцеву діяльність вдалося відновити. Зважаючи на великий об'єм резекції, хворому була показана торакопластика, проте через ускладнення операцію терміново закінчили. В післяопераційному періоді у пацієнта тривалий час оперована легеня не розправлялась повністю. Хворому здійснювали активну аспірацію і санацію залишкової плевральної порожнини. Майже через 3 міс післяопераційного лікування вдалося розправити оперовану легеню. 


\section{Обговорення}

Є багато повідомлень та рекомендацій зарубіжних дослідників щодо хірургічного лікування аспергільозу легень, проте всі вони грунтуються на малій кількості спостережень. Найбільш сучасну та доказову лікувальну тактику при аспергільозі легень запропоновано Американським товариством 3 інфекційних захворювань [9], зокрема виконувати оперативні втручання у разі ураження легень у безпосередній близькості до великих судин та перикарду; інфікуванні перикарду; залучення грудної клітини в інфекційний процес; аспергільозної емпієми; кровохаркання з одиничного вогнища легеневої тканини.

Проте приймати рішення про оперативне лікування слід індивідуально щодо кожного пацієнта з урахуванням різних факторів, включаючи вид та об'єм резекції (атипова чи типова), супутню патологію, загальний стан хворого. Хірургічне втручання, якщо діагноз аспергільозу встановлено, слід виконувати після курсового прийому антимікозних препаратів і досягнення клініко-рентгенологічної стабілізації процесу, причому перевагу слід віддавати анатомічній резекції. Оптимальним резекційним оперативним втручанням вважається лобектомія. Виконання сегментектомії завжди пов'язане з ризиком неповної резекції, що призведе до рецидиву захворювання. 3 іншого боку, пневмонектомія є надзвичайно ризикованим оперативним втручанням з огляду на велику кількість інтра- та післяопераційних ускладнень (інфекційних та геморагічних).

Традиційно вважається, що ризик післяопераційних ускладнень при аспергіломі дуже високий (25 - 56,7\%) $[6,10]$. Найбільш типовими післяопераційними ускладненнями є: інтраплевральна кровотеча, тривалий скид повітря, емпієма залишкової плевральної порожнини з бронхіальною норицею. Також часто в післяопераційному періоді виникають кардіогенні порушення. Післяопераційна летальність сягає 23\% [1].

S. Correia Sda повідомив про хірургічне лікування аспергіломи легені у 22 хворих. Частота післяопераційних ускладнень склала 36,4\%, інтраопераційна летальність $4,5 \%[10]$.

B. Mohapatra і співавтори поділилися досвідом лікування складної аспергіломи легені у 24 хворих, 22 (91,0\%) 3 них мали туберкульозний анамнез. У 79,2\% хворих було кровохаркання. Лобектомія виконана 16 (66,7\%) пацієнтам. Післяопераційні ускладнення виникли у 33,3\% хворих. Летальних випадків за період спостереження до 2 років не було [11].

M. M. El Hammoumi повідомив про результати лікування складної (у 61 хворого) і простої (у 54) аспергіломи легені. Частота післяопераційних ускладнень склала 16,0 і 9,0\% відповідно [7].

K. Aydoğdu і співавтори прооперували 77 пацієнтів 3 аспергіломою легені. У 52 (67,5\%) хворих показанням до операції було рецидивуюче кровохаркання. Післяопераційні ускладнення виникли у 23,4\% хворих, післяопераційна летальність склала 3,9\% [5].
Окремого вирішення потребує питання виконання торакопластики пацієнтам з аспергіломою, яким показане резекційне втручання. Легеня після резекції внаслідок значного злукового процесу в плевральній порожнині втрачає свої еластичні властивості та досить часто не в змозі заповнити весь післяопераційний простір. Це призводить до утворення залишкової плевральної порожнини, перерозтягнення легені з формуванням бронхо-плевральної нориці та інфікуванням плевральної порожнини. Тому існує дві думки з цього приводу: інтраопераційне вирішення та одномоментне виконання торакопластики і виконання торакопластики через 2-3 тиж у випадку наявності залишкової плевральної порожнини $[2,5,10,11]$. В нашій клініці, за необхідності, виконуємо одномоментну інтраплевральну торакопластику.

\section{Висновки}

1. Хірургічне лікування аспергільозу легень $є$ досить складним завданням, багато питань потребують вирішення.

2. Систематизація власного досвіду в поєднанні 3 досягненнями інших клінік забезпечує покращення надання допомоги даному контингенту хворих.

\section{References}

1. Liskina IV, Kuzovkova SD. Aspergilloma legkogo. Mezhdunarodnyj medicinskij zhurnal. 2011. Dec;17(4):41-8. [In Russian]

2. Demir A, Gunluoglu MZ, Turna A, Kara HV, Dincer SI. Analysis of surgical treatment for pulmonary aspergilloma. Asian Cardiovasc Thorac Ann. 2006 Oct;14(5):407-11.

3. Kawamura S, Maesaki S, Tomono K, Tashiro T, Kohno S. Clinical evaluation of 61patients with pulmonary aspergilloma. Intern Med. 2000 Mar;39(3):209-12.

4. Kravec VA, Gavrisjuk IV. Aspergillez legkih: klinicheskie formy, diagnostika, lechenie. Ukrainskij pul'monologicheskij zhurnal. 2015. Dec; 4:69-74. [In Russian]

5. Aydoğdu K, İncekara F, Şahin MF, Gülhan SŞ, Findik G, Taştepe İ, et al. Surgical management of pulmonary aspergilloma: clinical experience with 77 cases. Turk J Med Sci. 2015;45(2):431-7.

6. Al-Alawi A, Ryan CF, Flint JD, Müller NL. Aspergillus-related lung disease. Can Respir J. 2005 Oct;12(7):377-87.

7. El Hammoumi MM, Slaoui O, El Oueriachi F, Kabiri el H. Lung resection in pulmonary aspergilloma: experience of a Moroccan center. BMC Surg. 2015 Oct 16;15:114.

8. Sagan D, Goździuk K, Korobowicz E. Predictive and prognostic value of preoperative symptoms in the surgical treatment of pulmonary aspergilloma. J Surg Res. 2010 Oct;163(2):e35-43. doi: 10.1016/j. jss.2010.06.039.

9. Maschan AA, Klasova GA, Veselov AV. Lechenie aspergilleza: obzor rekomendacij amerikanskogo obshhestva po infekcionnim boleznjam. Klinicheskaja mikrobiologija i antimikrobnaja himioterapija. 2008. Jun; 10(2):133-70. [In Russian]

10. Correia Sda S, Pinto C, Bernardo J. Pulmonary aspergilloma surgery: a mono-institutional experience. Acta Med Port. 2014 JulAug;27(4):417-21.

11. Mohapatra B, Sivakumar P, Bhattacharya S, Dutta S. Surgical treatment of pulmonary aspergillosis: A single center experience. Lung India. 2016 Jan-Feb;33(1):9-13. 